\title{
Contamination of white clover seed crops by buried seed
}

\author{
J.G.H. WHITE, G.R. EDWARDS and K. NICHOLSON
} Plant Science Department. P.O. Box 84. Lincoln University

\begin{abstract}
The first study examined white clover seed loss in the offal trail of a header harvester. Seed counts in offal trails were $83800 / \mathrm{m}^{2}$ compared to intermediate areas at $22500 / \mathrm{m}^{2}$. Consequent problems in sampling for buried seed are discussed. The second trial measured buried seed two years after a white clover seed crop. In the top $25 \mathrm{~cm}$ of soil 66200 seeds $/ \mathrm{m}^{2}$ remained following conventional cultivation but only 26000 occurred under direct drilling. With conventional cultivation $80 \%$ of seed was buried below $10 \mathrm{~cm}$ depth, but $63 \%$ of the buried seed was in the $0-5 \mathrm{~cm}$ layer with direct drilling. In a third study the rate of hard seed breakdown was examined. Breakdown was rapid on the surface but after4 years $36 \%$ of seed survived at 10 $\mathrm{cm}$ depth and $65 \%$ at $20 \mathrm{~cm}$ buried. The practical implications on cultivation practices required to permit change of cultivars without contamination problems are discussed.
\end{abstract}

Keywords Trijblium repens L., buried seed, offal trail, direct drill, conventional cultivation, burial depth

\section{Introduction}

The white clover (Trifolium repens L.) cultivar Grasslands Huia has until recently supplied up to $70 \%$ of the world's white clover seed trade. However, the release of Grasslands Pitau, Tahora and Kopu. combined with the increased practice of multiplying overseas cultivars for re-export has resulted in increased areas of white clover cultivars other than Huia for seed production. There are problems in maintaining purity of these new cultivars due to contamination resulting from buried white clover seed in soil (Lancashire et al. 1985). This buried seed bank is largely derived from Huia seed crops, although new cultivars are now contributing to the problem.

Because of a lack of information on a number of aspects related to the fate of buried seed in the field, three experiments were conducted. The objective of the first experiment was to examine losses of seed from the offal trail of the header harvester as it affects buried seed counts. The second experiment examined the distribu- tion of buried seed in the soil profile following diit drilling or conventionally cultivating after a white clover seed crop. The third experiment measured the fate of white clover seed over time when buried at various depths.

\section{Experiment 1. Losses of seed from the offal trail}

This experiment was conducted in a Huia white clover seed paddock on the Lincoln University mixed cropping farm. The crop was mown on 31 January and 3 February 1986 and subsequently harvested on 11 and 12 February using a Murphy pickup on the harvester.

Forty-five 5-m sampling lengths in each of the offal trail and intermediate areas were. located over the paddock, and on 19 February ten S-cm soil cores were taken at $0.5-\mathrm{m}$ intervals along the 5-m sampling areas and the cores bulked. White clover seed was extracted from the soil using a standard technique of the Seed Testing Station, Palmerston North (D.J. Scott pers. comm.).

White clover seed counts in the offal trail were almost four times the number in the intermediate area (Table 1).

Table 1 White clover seed counts in the offal trail and intermediate areas of white clover seed paddock following harvest.

\begin{tabular}{|c|c|c|c|c|c|}
\hline & & \multicolumn{2}{|c|}{ Mean } & \multicolumn{2}{|c|}{ Range } \\
\hline & & $\mathrm{No} / \mathrm{m}^{2}$ & kg/ha & $\mathrm{No} / \mathrm{m}^{2}$ & kg/ha \\
\hline $\begin{array}{l}\text { Offal trail } \\
\text { Intermediate }\end{array}$ & area & $\begin{array}{r}83,800 \\
22,500\end{array}$ & $\begin{array}{c}5943,600 \\
159 \quad 7,200\end{array}$ & $\begin{array}{r}156,000 \\
0 \quad 48.000\end{array}$ & $\begin{array}{c}26 \cdot 1105 \\
51-340\end{array}$ \\
\hline $\begin{array}{l}\text { SEM } \\
\text { Signif. }\end{array}$ & & $\begin{array}{r}3,803 \\
P<0.00\end{array}$ & & & \\
\hline
\end{tabular}

\section{Experiment 2. Effect of cultivation on bur- ied seed distribution}

Paddock Al5 on the University mixed cropping farm was divided in half and used as a direct drill-conventional cultivation comparison from 1981 to 1986 . In 1984 a volunteer white clover seed crop was harvested. followed by wheat and barley crops. The paddock was sampled for buried white clover seed in March 1986. 
Each half paddock was divided into 5 replicates and 10 random samples were taken per replicate using a $\mathbf{2 . 5} \mathbf{- c m}$ diameter corer to $25 \mathrm{~cm}$ depth. The cores were subdivided into S-cm sections for buried seed analysis using the same technique as Experiment 1 . The viability of seed was determined by germination tests both before and after scarification.

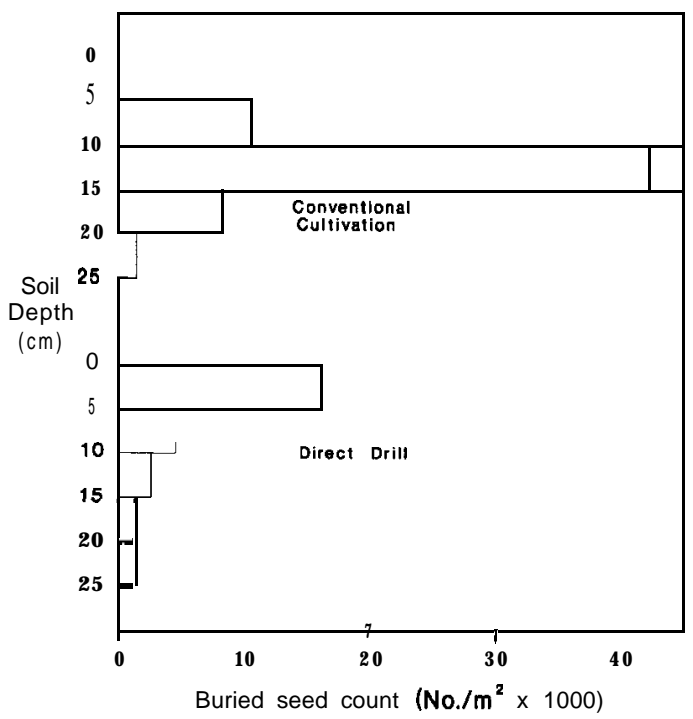

Figure 1 The effect of conventional cultivation and direct drilling on distribution of white clover seed aftera white clover seed harvest (Signif. $P<0.001$ ).

Tillage treatment caused a significant difference in the depth of distribution of residual white clover seed (Fig. 1). With conventional cultivation buried seed counts increased to a maximum of $42200 \mathrm{seeds} / \mathrm{m}^{2}$ at $10-15 \mathrm{~cm}$ depth. but with direct drilling buried seed count was highest in the surface $5 \mathrm{~cm}$ of soil (16 000 seeds $/ \mathbf{m}^{2}$ ) and declined with increasing depth. Total buried seed in the top $25 \mathrm{~cm}$ of soil was significantly greater in the conventionally cultivated than in thediiect drilled treatments (Table 2).

Table 2 The effect of conventional cultivation and direct driling on total buried white clover seed number.

\begin{tabular}{lcl}
\hline & Treatment & \\
& $\begin{array}{c}\text { Conventional } \\
\text { cultivation }\end{array}$ & $\begin{array}{c}\text { Direct } \\
\text { drill }\end{array}$ \\
\hline Seed number $/ \mathrm{m}^{*}$ & 66,200 & 26,000 \\
SEM & $\begin{array}{c}1115 \\
\text { Signif. }\end{array}$ & $\mathbf{P}<\mathbf{0 . 0 0 1}$ \\
\hline
\end{tabular}

The amount of buried white clover seed in the soil was very high for both treatments. Tillage treatment and depth of burial had no effect on either the percentage of soft seed, or the percentage which germinated after scarification but $89 \%$ of seed in the direct drilled area was viable, but only $73 \%$ where cultivation was conventional.

\section{Experiment 3. Effect of depth of burial over time}

The trial was initiated by J.D.R. Holloway in March 1986. when lots of 200 hard seeds of white clover were mixed with soil and placed in nylon bags at 0.2.10 and $20 \mathrm{~cm}$ depth (Holloway, 1987). Eight replicates were exhumed after 6 and 9 months (Holloway, 1987) and again in 1990. The only bags that remained after four years were at 10 and $20 \mathrm{~cm}$ depth.

The surviving white clover seeds were extracted from the soil in the bags and the seeds germinated before and after scarification. Table 3 presents the results in comparison with those obtained by J.D.R. Holloway after 6 and 9 months (Holloway 1987).

Table 3 The number of white clover seeds recovered over time from 200 buried initislly

\begin{tabular}{lccc}
\hline Burial period & 6 months' & 0 months' & 4 years \\
\hline Depth Ocm & 64 & $\mathbf{7 0}$ & \\
$2 \mathrm{~cm}$ & 151 & 137 & \\
$\mathbf{1 0 c m}$ & 153 & 156 & $\mathbf{7 4}$ \\
$20 \mathrm{~cm}$ & 165 & $\mathbf{1 5 7}$ & $\mathbf{1 2 9}$ \\
& & & \\
CV\% & 11.3 & 16.0 & $\mathbf{2 8 . 0}$ \\
SEM & $\mathbf{0 . 3}$ & $\mathbf{0 . 0}$ & 10.1 \\
\hline
\end{tabular}

- Data from Holloway (1987)

The number of seed surviving on the surface was almost half that at greater depth after 6 months, and after nine months the number at $2 \mathrm{~cm}$ had also declined. After four years, the number of seed at $10 \mathrm{~cm}$ depth had declined 53\% compared to the number at nine months, but had declined by only $18 \%$ at $20 \mathrm{~cm}$ depth of burial.

No differences were measured in the percentage of seed which germinated before or after scarification.

\section{Discussion}

A high proportion of the white clover seed recovered in the offal trail experiment is likely to reflect direct harvesting losses. The seed loss in the offal of $594 \mathrm{~kg} / \mathrm{ha}$ is consistent with that reported by Clifford \& McCartin (1985) who found in the seven crops they surveyed that 
total seed loss in the offal trail ranged from $464-745 \mathrm{~kg} /$ ha for a variety of harvesters and harvesting conditions. However the intermediate area counts of $159 \mathrm{~kg} / \mathrm{ha}$ are lower than the mowing and pickup losses of $294490 \mathrm{~kg} /$ ha measured by the same authors.

At present, buried seed sampling requires 50 cores on a "line basis" from all areas of a field. Because the distribution of buried seeds across a paddock will be influenced by the position of offal trails, random sampling is essential to ensure offal trails or intermediate areas are not ssmpledrepeatedly. However, when interpreting results it is important to realise that while soil counts may meet requirements for white clover seed certification there may be bands in the paddock with seed levels far exceeding certification rules. Further work is also needed to improve harvesting techniques so that seed losses from the offal trail are minimised.

The pattern of declining seed loss with increasing depth of burial is supported by Taylor (1984) for subterranean clover. Seeds close to the soil surface are subject to greater temperature and moisture fluctuations than at deeper levels, and high levels of softening will occur at this location. Once seeds are softened they either germinate or die. In the depth of burial trial described here it appears that temperature and moisture fluctuations as deep as $10 \mathrm{~cm}$ were sufficient to soften a proportion of the seed after four years' burial, but the effect was minimal at $20 \mathrm{~cm}$ depth. The results of the cultivation experiment support those obtained in the depth of burial trial. Assuming that the amount of seed present in the soil following the harvest in 1984 was similar, the rate of seed breakdown over two years under direct drilling was much greater that with conventional cultivation. This was related to the distribution of the seed in the soil profile, as most of the seed in the direct drilled area was in the surface $5 \mathrm{~cm}$ while seed in the conventionally cultivated area was buried at $10-15 \mathrm{~cm}$ and insulated from temperature and moisture fluctuations. Clifford $\boldsymbol{e}$ al. (1990) advocate deep ploughing after harvest to bury the large numbers of white clover seeds lost at harvest and bring soil largely free of buried seed to the germinating zone. Over the following five years they recommend direct drilling or shallow surface cultivation to keep the seed buried. Ourresults wouldconfirm this as a practical approach, although care is needed to avoid a deep ploughing, which could return a large proportion of the buried seed to the germinating zone to act as possible contaminants.

\section{ACKNOWLEDGEMENTS}

Sandra Hines, who carried out most of the seed analyses.

\section{REFERENCES}

Clifford, P.T.P.; Baird, I.J.; Grbavac, N; Sparks, G.A. 1990. White clover soil seed loads: effect on requirements and resultant success of cultivarchange crops. Proceedings of the New Zealand Grassland Association 52: 95-98.

Clifford P.T.P.; McCartin, S.J.M. 1985. Effects of preharvest treatment and mower and header types on seed loss and hard seed content at mowing, recovery and separation when harvesting a white clover seed crop. New Zealand Journal of Experimental Agriculture 13: 307-316.

Holloway, J.D.R. 1987. Seed production and loss in white clover (Trifolium repens L.) M.Agr.Sc. thesis, Lincoln College. University of Canterbury.

Lancashire, J.A.; Rolston, M.P.; Scott, D.J. 1985. Contamination of white clover seed crops by buried seed.In Hare, M.D. and Brock J.L. (eds) Producing herbage seeds. Grasslands Research and Practice Series No. 2 61-65. N.Z. Grassland Association.

Taylor, G.B. 1984. Effect of burial on the softening of hard seeds of subterranean clover. Australian Journal of Agricultural Research 35: 201-210. 